\title{
Foundations of Mindfulness
}

The buddhalakșana 'characteristics of the Buddha' outlined in the article by Levman in this issue may be seen in the context of the 32 body parts as object of meditation in the mahāsatipațthāna sutta 'Foundations of Mindfulness Discourse' of the Pali Canon (DN, xxii.5) (see Nyanaponika Thera, The Heart of Buddhist Meditation, 1954, Samuel Weiser, for a discussion):

There are in this body head hair, body hair, nails, teeth, skin, flesh, sinews, bones, marrow, kidneys, heart, liver, pleura, spleen, lungs, intestines, mesentery, stomach, feces, bile, phlegm, pus, blood, sweat, fat, tears, grease, saliva, mucus, synovic fluid and urine [and brain*].

*'Brain in the skull,' added later, makes up the $32^{\text {nd }}$ part.

atthi imasmim kāye kesā lomā nakhā dantā taco maṃsạ̣ nahāru aț̣hi aț̣himinjā vakkam hadayam yakanam kilomakạ̣ pihakaṃ papphāsaṃ antạ̣ antagunạ̣ udariyaṃ karisaṃ pittam semhạ̣ pubbo lohitạ̣ sedo medo assu vasā khelo singānikā lasikā muttan $t i *$.

*Later additon: ... matthake matthalungam.

The meditator comes to this 'reflection on the Repulsiveness of the Body' as part of the 'Contemplation of the Body' beginning with the breath. For details of the meditative practice, see The Path of Purification (Visuddhimagga), by Buddhaghosa, ch. VIII, 8.

On the opposite page is a visual representation of the 32 body parts (excerpted from Commemorative Souvenir, 100 years of Buddhism in Canada, NCBS, 2005, p.22), originally developed (by Suwanda H. J. Sugunasiri) as a visual aid in relation to anga dāna 'organ donation'. 
$\underline{\text { Solid }}$

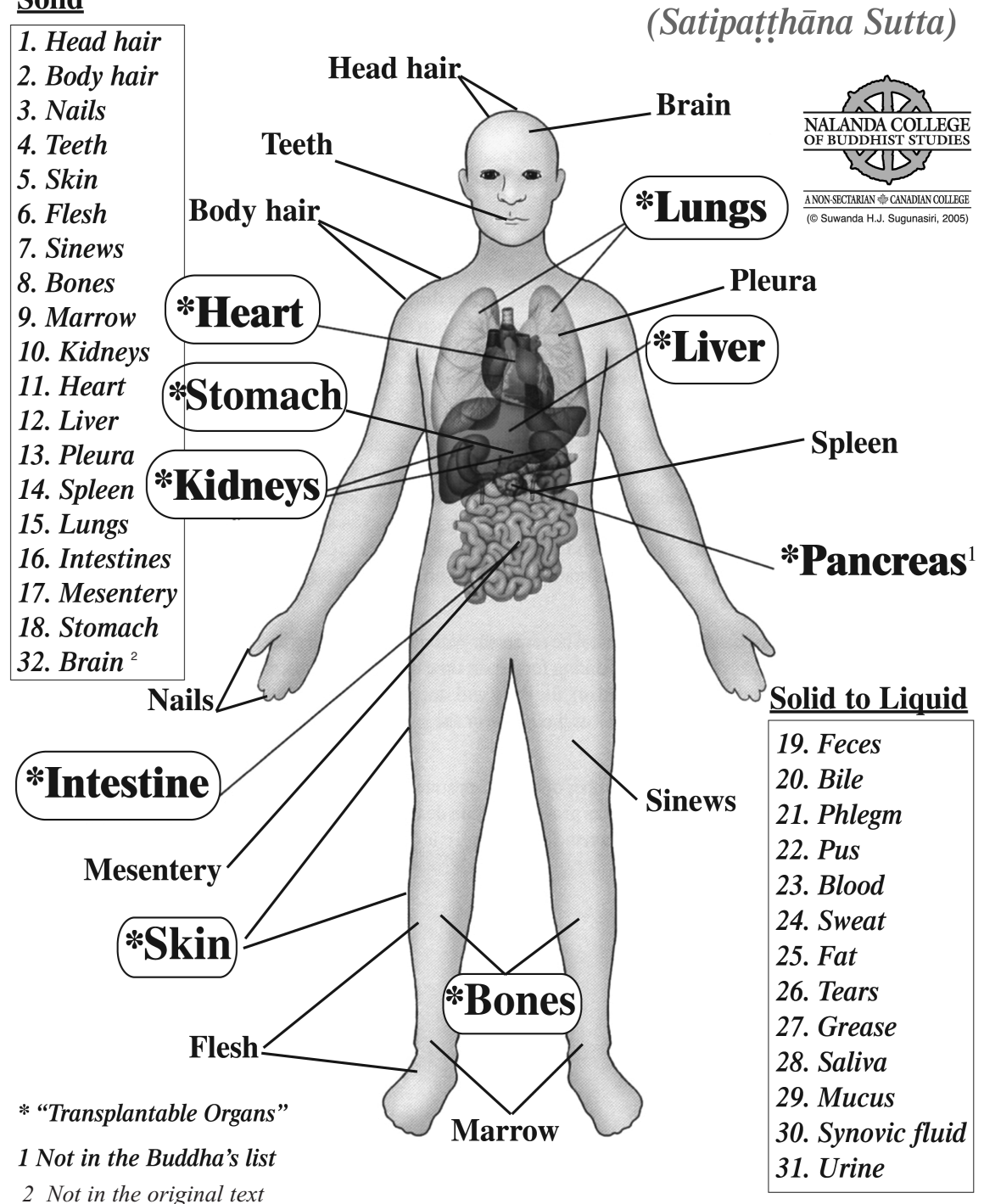
(Satipatțhāna Sutta)

\section{The Human Body (the 32 parts)-} Buddha's Analysis, 543 B.C.E. 